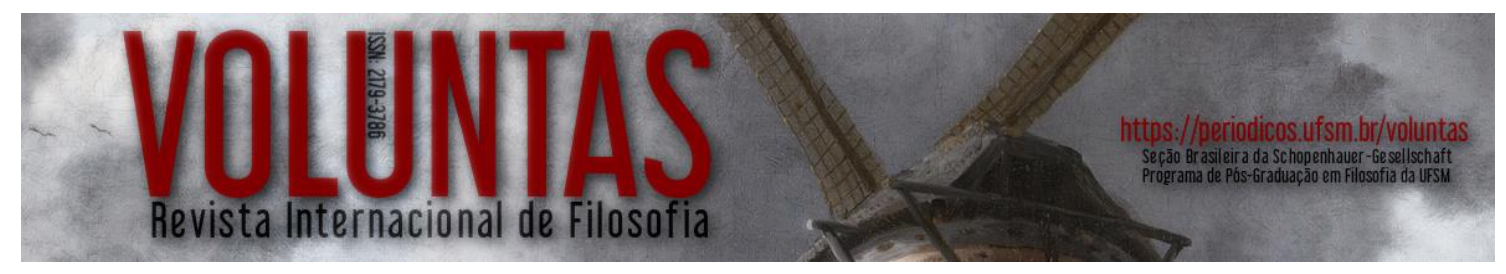

ISSN: 2179-3786

DOI: $10.5902 / 2179378636053$

\title{
Schopenhauer e o teatro: ilusão, resignação e sabedoria de vida
}

\author{
Schopenbauer and the theater: illusion, resignation and wisdom of life
}

Eduardo Ribeiro da Fonseca

Professor do Programa de Pós-Graduação em Filosofia da PUCPR Coordenador do GT de Filosofia e Psicanálise da ANPOF

E-mail: eduardorfonseca@uol.com.br

Resumo: Nosso texto pretende evidenciar aspectos da relação entre o teatro como forma de arte e como metáfora da experiência humana na filosofia de Schopenhauer, partindo das considerações sobre (a) o quadro objetivo da existência como conservação, sexualidade e morte, (b) da tragédia como dramatização do conflito íntimo da vontade e resignação a esse quadro objetivo da existência e (c) da sabedoria de vida como um teatro no qual a marionete humana veste uma fantasia de porcoespinho para encontrar a distância mais adequada em relação às outras pessoas, que para ela representam o calor da proteção, da segurança e da compaixão, mas por outro lado, representam também os aguilhões das outras vontades individuais carentes e famélicas como a sua.

Palavras-chave: Existência; Tragédia; Resignação; Ilusão; Sabedoria.

Abstract: Our text intends to highlight aspects of the relationship between theater as an art form and as a metaphor in Schopenhauer's philosophy, starting from the considerations about (a) the objective framework of existence as conservation, sexuality and death, (b) the tragedy as dramatization of conflict intimacy of the will and resignation to this objective picture of existence and (c) the wisdom of life as a theater in which the human puppet wears a porcupine costume to find the most adequate distance from other people who represent it the warmth of protection, security and compassion, but on the other hand, they also represent the stings of other needy and starved individual wants like yours.

Keywords: Existence; Tragedy; Resignation; Illusion; Wisdom.

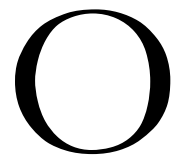

estudo dos sentidos possíveis que a noção de teatro adquire especialmente nos "Complementos" (Ergänzungen) de 18441 ao livro O Mundo como Vontade e Representação (1818 [1819]), mas também em outros pontos da obra de Arthur Schopenhauer, leva-nos à consideração de suas dimensões como drama e tragédia, pelo que nos faz entrever o conflito inerente à vontade e, em sua dimensão ética nos conduziria talvez à resignação (o que é veementemente negado por Nietzsche, que vê na tragédia a própria tentativa de autossuperação trágica do homem grego); por outro lado, o teatro é pensado pelo filósofo também do ponto de vista do

\footnotetext{
${ }^{1}$ W II: O Mundo como Vontade e Representação: Complementos. Tradução do alemão e notas de Eduardo Ribeiro da Fonseca.
} 
mundo objetivo, da condição humana e, não menos importante, da sabedoria de vida, ou seja, da filosofia prática. O percurso a ser feito no presente artigo é primeiramente o de situar o quadro objetivo da existência presente na filosofia de Schopenhauer como algo repetitivo, essencialmente recorrente, insatisfatório, cindido entre as diversas manifestações do egoísmo e da voracidade do querer-viver, para extrair disso as suas figuras fundamentais: a conservação, a sexualidade e a morte. Depois, veremos como os véus são jogados sobre essa existência, recobrindo-a de charme e de encanto, fazendo de nós marionetes em um teatro de fantoches. Em seguida, veremos como o drama, especialmente a tragédia, retrata o conflito inerente à vontade e nos conduziria, como foi dito acima, à resignação que nega o otimismo e afirmaria, de seu ponto de vista, o pessimismo na arte. $\mathrm{Na}$ terceira parte veremos como Schopenhauer, no âmbito de sua filosofia prática, sugere que é essencial que em nossa existência mundana utilizemos máscaras e encaremos a vida cotidiana como um teatro de aparências no qual delimitamos o nosso papel, o que depende de nós, e, consequentemente, o modo como atuamos objetivamente no palco da sociedade.

No conjunto desses três pontos de vista, a Humanidade é vista como parte da natureza, e, portanto, a nossa existência ao longo de Eras seria como um teatro no qual se repetiria o que já ocorre no mundo natural. Nessa cena universal nós acrescentaríamos apenas novos alvos mais adequados à nossa autoconsciência e às formas específicas de cultura humana. Também em nossa sociedade, como na natureza, mudam os atores, os figurinos, os diálogos, até a casa de espetáculos, mas a peça seria sempre tediosamente a mesma. Esta Humanidade da qual participamos, “inumerável através do seu ser constantemente renovado, incessantemente se agita, é impulsionada, impelida adiante, preocupando-se, lutando e realizando toda a tragicomédia da história mundial" (W II, 2, p. 515). Mas, o que fundamenta tudo isso? Trata-se do simples e cego impulso da Vontade que está inteira em cada um desses inumeráveis indivíduos semiconscientes, capazes de falar de si, mas incapazes de fundamentar as suas próprias motivações ao fundo das razões e motivos um tanto equivocados pelos quais percebem e descrevem a si mesmos.

\section{A Humanidade no quadro objetivo da natureza: o teatro de marionetes do querer-viver}

Para o filósofo da vontade, é deveras impressionante verificar o contraste representado pelos dois aspectos de nossa experiência cotidiana: Se, por um lado, admitimos o indescritível tumulto que caracteriza a afirmação da vida, os esforços, cuidados, responsabilidades e a incessante necessidade sob os quais os organismos vivem, por outro, temos que admitir também a impossibilidade de satisfação mediante os alvos da nossa existência prática pelos quais pretendemos não apenas ser felizes, mas assim permanecer no decurso do tempo. Ao final, tudo se resumiria a comer, reproduzir e, após cumprir essa simples missão, finalmente ser descartado e morrer. 
Esse é o ciclo da experiência empírica da individuação ${ }^{2}$. $\mathrm{O}$ saldo da existência, como resultado de um absurdo dispêndio de tempo e depois de muitas esperanças, promessas, privações e decepções, seria uma vida apenas tolerável com a certeza da morte ao fim de uma existência atormentada por dúvidas e sofrimentos. Assim, vivemos no palco de uma vida fútil, governada por impulsos e motivos tão incontroláveis como inconciliáveis com a felicidade duradoura ${ }^{3}$. A Humanidade e sua existência (na sua completude e universalidade) surgiriam então, dessa forma, diante de Schopenhauer, como um "teatro de marionetes" a despeito da aparência de finalidade particular que acreditamos ver em nossos atos. Mas os seres humanos não são controlados apenas por cordões externos, a partir da necessidade exterior - pelos objetos externos ou motivos - como marionetes comuns; pelo contrário, do ponto de vista do filósofo, somos controlados fundamentalmente por um mecanismo interno, como um "relógio que funciona sem saber por que" (W II, 2, p. 463):

É a Vontade de vida manifestando a si mesma como um incansável mecanismo, como um impulso irracional, o qual não tem sua razão suficiente no mundo externo. Ela mantém os indivíduos em seus cenários e é o primum móbile de seus movimentos; enquanto que os objetos externos, os motivos, determinam meramente a direção desses movimentos no caso específico, pois de outra maneira a causa não poderia ser em qualquer caso apropriada ao efeito (Ibidem, p. 464).

Para o filósofo, assim como toda manifestação de uma força natural tem uma causa, mas a força mesma não a tem, igualmente todo ato da Vontade tem um motivo, mas a Vontade em si mesma não pode ser referida a uma causa. É um sem-fundo sob a aparência de ordem dada pelos motivos que excitam a vontade humana, como a luz excita a vontade da planta.

$\mathrm{O}$ ato volitivo, fundamentado em um motivo, e a Vontade em geral, são uma e mesma coisa, apenas ocorre que o primeiro está conectado ao mundo empírico, enquanto que a Vontade em geral é a fonte irredutível de qualquer ação e não pode ser em si mesma condicionada externamente, até porque é inconsciente (ibidem, p. 259) justamente porque essa Vontade está, enquanto querer-viver, na base da expressão fenomênica, que o homem ama, acima de qualquer coisa, a própria vida, apesar de estar cheia de necessidades, tristezas, problemas, dor, ansiedade e tédio. Após comparar a quantidade de sofrimento a que uma pessoa é submetida, com a felicidade de que ela desfruta, o filósofo conclui que "a vida é um negócio cujo retorno é insuficiente para cobrir seus custos" (ibidem, p. 457), muito embora o amor pela vida nos iluda e com isso nos traga falsas esperanças. Trata-se de uma visão que está baseada em um argumento de custo e benefício, que, talvez, seja demasiado

2 FONSECA, Psiquismo e Vida: Sobre a noção de Trieb nas obras de Frend, Schopenhauer e Nietzssche, p. 201.
${ }^{3}$ Idem.

Voluntas: Revista Internacional de Filosofia - periodicos.ufsm.br/voluntas - Santa Maria - Vol. 9, n. 1, jul.-dez. 2018, p. 67-83. 
quantitativo para expressar a verdadeira natureza do problema que representa o valor da existência. A transitoriedade, a doença, a certeza do sofrimento e da morte serão mesmo argumentos contra a vida?

De qualquer modo, para ele, não é a Vontade que aparece em consequência do mundo, mas sim o mundo é que aparece em consequência da Vontade. Isto se dá à força de um mecanismo compulsório, inacessível ao conhecimento imediato, e que pressupõe o sofrimento, visto como condição ao fundo de todo e qualquer esforço humano pela felicidade. O conjunto do funcionamento da natureza exaure, corrompe, aniquila nossas forças individuais, até que o golpe final da morte se abata sobre cada um. Ainda que tais situações em nada afetem a continuidade da vida da espécie (W I, p. 280$)^{4}$.

Se considerarmos a agitação infrutífera da existência, continuamente caindo no abismo e ao abismo retornando, não podemos deixar de olhar em volta e perguntar o que resulta de todo o esforço que empregamos para viver, em suma, devemos perguntar o que resulta de tudo isso, e qual alvo é atingido pela existência animal que exige tantos e tão enormes preparativos de cada ser que contempla o nascer do sol. Segundo Schopenhauer, quanto a isso não há nada para mostrar, além da satisfação da fome e do impulso a exercer a sexualidade. Em qualquer caso, a gratificação é apenas momentânea para o indivíduo, ela é tudo, mas ocorre apenas eventualmente, entre as séries intermináveis de tentativas de satisfação das necessidades e esforços. Se colocarmos as duas coisas juntas, o engenho inexprimível dos preparativos, a riqueza incalculável dos recursos, e, em contraposição, a inadequação do que é assim buscado e atingido, somos levados a concluir que a vida é deficitária. Quanto mais simples o animal, maior o grau de automatismo das ações. Nesse sentido, fica claro para o filósofo que as preocupações e os problemas da vida estão fora de proporção ao "rendimento ou lucro que se tem com isso" (W II, 2, p. 512). A consciência do mundo intuído, no entanto, dá uma aparência de valor objetivo à existência desses animais, apesar de tal consciência ser totalmente subjetiva e limitada pela influência de motivos, isso é de objetos que se colocam como satisfatórios para o querer. Assim, para ele a futilidade e a inutilidade da luta de todo ser fenomênico são mais facilmente compreendidos na vida simples e facilmente observável dos animais. A variedade e a multiplicidade das formas de organização, a perfeição artística dos meios pelos quais cada um se adapta ao seu elemento e à sua presa, contrastam claramente com a ausência de qualquer objetivo duradouro. Em vez disso, vemos apenas satisfação momentânea, o prazer fugaz condicionado pela necessidade, muito sofrimento em

\footnotetext{
${ }^{4}$ Schopenhauer metaforiza esse mecanismo incansável do sofrimento empírico através de mitos gregos como o da "roda de Íxion". Assim como em Freud, o eterno retorno do querer-viver tem como contrapartida a certeza da morte do organismo individual, mas há também em Schopenhauer o nunc stans, aquilo que é um imóvel e eterno presente na experiência humana, como um arco-íris imóvel diante da rumorejante vida da Humanidade.
}

Voluntas: Revista Internacional de Filosofia - periodicos.ufsm.br/voluntas - Santa Maria - Vol. 9, n. 1, jul.-dez. 2018, p. 67-83. 
longo prazo, "pressão, desejo, necessidade e gritos, ansiedade e uivos, e isto continua saecula saeculorum, ou até que mais uma vez se quebre a crosta do planeta". (Ibidem, p. 513) É interessante refletir a partir de Schopenhauer sobre a recorrência de tudo o que existe, desde que as mesmas condições se repitam. A Humanidade pode desaparecer mil vezes, assim como o mundo, e, dadas as mesmas condições, tudo potencialmente reaparecerá. É assim que o querer-viver se objetiva, tal é a sua natureza e a do mundo. Porém, ninguém sabe a razão pela qual toda essa tragicomédia existe, pois ela não tem espectadores, já que não existem deuses na filosofia de Schopenhauer, e "os atores em si mesmos passam por preocupações intermináveis e problemas, usufruindo pouco e de modo meramente negativo". O ser humano torna a peça mais complicada, mas, o caráter fundamental do drama da existência permanece inalterado. Aqui a vida também "não se apresenta de maneira nenhuma como um presente a ser desfrutado, mas como uma tarefa a ser executada" (W II, 2, p. 514). O teatro humano é pleno de atividade, mas ainda lembra em tudo o que já acontece na natureza, pois, ao fundo de toda a agitação da existência, ainda subsiste o mesmo ímpeto cego, o mesmo impulso sem finalidade que nos impele à vida. Neste espetáculo de marionetes dos impulsos, os bonecos humanos não são fundamentalmente puxados por cordões externos, pelos motivos. Ao contrário, deste ponto de vista, apresentam-se como marionetes que são postos em movimento por um mecanismo interno, pela motivação, que reside no caráter individual. Desse caráter provém a motivação inquebrantável que fundamenta a atividade inquieta das pessoas, os seus esforços incansáveis e os resultados pífios que obtêm. Para o filósofo a atividade humana não pode ser explicada, caso procuremos as causas motoras fora das personagens (Figuren), e concebamos que a raça humana atua em consequência de uma reflexão racional "ou de algo análogo à mesma (como fios que fossem puxados de fora), após as coisas boas serem apresentadas a ele e cuja realização seria uma recompensa adequada por seus tormentos e lutas incansáveis" (Idem). A explicação verdadeira está na "vontade de viver, que se manifesta como um mecanismo propulsor incansável, como um impulso irracional" (Idem). Desse modo, o determinismo permanece firme, mas o mecanismo, em Schopenhauer, deixa de ser algo externo e determinado por motivos, mas, pelo contrário, em sua filosofia é a necessidade cega quem dirige a peça, necessidade essa que ao fundo das causas aparentes submerge no torvelinho da vontade sem fundamento em razão suficiente, um mero ímpeto cego. A verdade paradoxal existente na relação entre a vontade e a causalidade está explícita em um capítulo de "Sobre a vontade na natureza", intitulado Physische Astronomie:

O antigo erro diz: Onde há vontade não existe causalidade alguma, e onde há causalidade não há vontade. Más nós dizemos: onde quer que haja causalidade há vontade, sem que esta obre jamais sem aquela. $\mathrm{O}$ punctum controversiae, é, pois, se podem e devem subsistir juntas e num mesmo momento a vontade e a causalidade, em um só e mesmo processo. O que 
dificulta a intelecção disto, de qualquer modo, é a circunstância de que a causalidade e a vontade nos são conhecidas de duas maneiras radicalmente diferentes: a causalidade inteiramente do exterior, inteiramente mediata, inteiramente através do entendimento; a vontade inteiramente do interior, inteiramente imediata; e que, por conseguinte, quanto mais clara seja a cada vez a inteligência de uma, tanto mais obscura será a da outra. Resulta que ali onde melhor soubermos da causalidade, menor será o conhecimento da vontade; e onde esta melhor se manifesta, o conhecimento da causalidade é diminuído ao ponto de um entendimento rudimentar se atrever a negá-la (SW III, N, p. 418).

Não há escapatória desse absurdo existencial a não ser admitir que é mesmo um paradoxo vivo o que caracteriza a existência, trata-se da admissão do conhecimento de que o ser e a essência de todas as coisas "são o fenômeno de uma Vontade realmente livre que se conhece precisamente neles, porque o seu agir e fazer não devem ser fornecidos a partir de necessidade" (W II 2, p. 514). Assim, "para salvar a liberdade do destino ou do acaso, ela teve que ser transferida da ação à existência" (idem). Isso é sem dúvida uma consideração vertiginosa: Não há plano diretor no âmbito do teatro da existência, ela é essencialmente livre e cega, mas, ainda assim, a necessidade crava simultaneamente suas garras no dorso da Humanidade no âmbito do agir. Isso se dá porque no âmbito da representação todo ser existente tem a vontade inteira dentro de si e não apenas uma parte dela e, simultaneamente ocorre o mesmo com uma miríade de seres. É a Vontade se autodevorando no âmbito da representação.

Mas, reforcemos o aspecto fisiopsicológico dessa relação. O ímpeto cego do querer-viver se configura de acordo com formas que existem na medida em que possibilitam a descarga dos impulsos, e, de um ponto de vista psíquico, sustentam a direção concreta do impulso em relação ao alvo de satisfação, que vai depender de o quanto esse ímpeto em certa direção potencializa e desenvolve o sistema psíquico através da possibilidade de antecipar a reação ao fenômeno conhecido. Nesse sentido, a representação correta de um objeto é originariamente apenas um meio com a finalidade de apreender e se apoderar cegamente da existência. O quantum determina a dinâmica das forças envolvidas e a configuração das formas que podem ser intuídas como representação. É apenas em um segundo momento (lógico e não histórico) que essa eficácia das forças e afetos se desenvolve e se torna mais complexa a ponto de se reconfigurar como causa e consequência, já que a memória se constrói justamente sobre esse fio de Ariadne das forças e dos afetos. Há uma memória das coisas, que configura a realidade por aquilo que nela se efetiva como efetivo e atuante, e só por isso se repete, e há uma memória propriamente dita, um instável acontecimento psíquico. Essa capacidade de lembrar se torna cada vez mais complexa na escala animal, até resultar naquilo que psiquicamente conhecemos efetivamente por memória humana, que é, em Schopenhauer, um mecanismo secundário ligado à 
representação, enquanto o fundamental, o essencial, permanece sempre o mesmo no eterno presente de uma vontade essencial e que desconhece (em si mesma) o tempo, o espaço e a causalidade. É justamente isso o que se transfere ao inconsciente do psiquismo schopenhaueriano como um mecanismo interno que controla os fios das marionetes humanas. Por essa razão os fios da necessidade não controlam efetivamente as pessoas, já que elas, devido ao mecanismo interno, são capazes de ações que seriam inexplicáveis pelo conhecimento causal da realidade. A realidade psíquica, nesse sentido, é um teatro subjetivo e nos lança diretamente ao serviço da vontade e à perseguição de seus alvos que ultrapassam em muito o interesse do indivíduo. É enredada no acaso e no erro que subsiste a personagem que protagoniza a tragédia humana, já que ela está dividida entre as polaridades de um conhecimento antecipatório autodivergente (pretende servir ao indivíduo, mas serve à sultana Vontade) vinculado ao querer-viver. Tal conhecimento prático não é suficiente para entender o sentido da existência, pois este ultrapassa em muito a possibilidade de previsão do sentido íntimo dos impulsos produzidos na secreta oficina da vontade, já que essa impetuosidade, o verdadeiro agente ao fundo da consciência, não depende de um regime causal e, portanto, não pode ser corretamente antecipada na experiência, mas apenas conhecida em retrospectiva por seus atos efetivos. Essa impotência humana diante de nossa própria excisão íntima resulta no caráter trágico da vida que é a marca d'água do pessimismo schopenhaueriano. Nas "Considerações transcendentes sobre a Vontade como coisa em si”, o filósofo menciona que o que está fora de nós apresenta uma determinação exclusivamente espacial, e o espaço é apenas uma forma de nossa intuição, ou seja, uma função de nosso cérebro. Portanto, para ele, o que parece estar fora de nós resulta de uma projeção dos objetos no exterior depois de ocorrida a sensação visual, que em si mesma reside em nossa cabeça, porque nela está o verdadeiro cenário da ação. "É como um palco no qual vemos montanhas, floresta e mar”, e, no entanto, tudo permanece no interior do teatro de nossas cabeças:

\begin{abstract}
As coisas não estão no espaço, e, por conseguinte, fora de nós, mas existem para nós como representações. Portanto, essas coisas que vemos diretamente (e não a sua simples imagem) são apenas as nossas representações e, como tais, existem apenas em nossas cabeças. Não é que, como dizia Euler, percebamos imediatamente as mesmas coisas situadas no exterior. Pelo contrário, as coisas percebidas por nós como estando situadas em nosso exterior são, na verdade, apenas nossas representações e, consequentemente, elas são o que nós percebemos imediatamente (W II, 1, p. 467).
\end{abstract}

Nossa cabeça é, então, uma casa de espetáculos no interior da qual é encenado o drama inteiro do universo, do planeta, da natureza, das culturas e das sociedades, bem como de nossa própria presença e formas de subjetividade em meio a tudo isso. 


\section{Schopenhauer e o trágico: resignação, destino e acaso}

Para Schopenhauer, o propósito do drama geralmente é nos mostrar o que são a essência e a existência das pessoas. Mas, o que é o principal, seria a essência que estaria ligada ao caráter ou seria a existência, para ele ligada ao destino, aos eventos, à ação? Essa é uma questão aristotélica retomada por ele. Para Aristóteles é o caráter elevado de quem age o que fundamenta a tragédia, considerada em relação à comédia, e não a ação. Mas é a ação, dada nas partes e na unidade dramática o que define a própria tragédia como composição, e não o agente e seu caráter. Percebe-se simultaneamente a distinção e seu entrelaçamento inevitável. Do mesmo modo, em Schopenhauer, ação e caráter se entrelaçam firmemente e não podem ser separados na apresentação, isto é, na própria estrutura do drama. Somente as circunstâncias, fatos e eventos fazem com que o caráter se manifeste e, mediante eles, na concepção de Schopenhauer, manifestam-se inevitavelmente. Nesse sentido, é próprio dos grandes poetas a caracterização do caráter das personagens de tal forma que em todas elas se manifestam com igual verdade e sinceridade, pelo que nos identificamos com todos e a partir deles percebemos o conflito inerente à exposição da vontade no mundo como representação.

A partir dessa constatação do funcionamento do drama da existência entre a vontade e a representação, aliás, bastante de acordo com o espírito da tragédia grega, veremos que, para o filósofo, o drama propriamente dito, como forma artística, especialmente a tragédia, retrata de maneira sublime (no caso, um sublime dinâmico) o conflito inerente à vontade, o lado terrível da vida, "o choro e a lamentação da humanidade, o domínio do acaso e do erro, aqueda dos justos, o triunfo dos maus", (W II, 2, p. 109.) pelo que seríamos "convidados a evitar a nossa vontade de viver", (Idem) o que, para ele, consequentemente, nos conduziria à resignação.

O que nos dá o sentimento trágico de tudo, a forma em que aparece, a tendência característica para o sublime, é o início do conhecimento de que o mundo e a vida não podem nos proporcionar nenhuma satisfação verdadeira, não sendo válido, portanto, o nosso apego a eles. É nisto que o espírito trágico consiste e por isso nos conduz à resignação (W II, 2, p. 110).

Resignation: O que isso significa? Significa a negação do otimismo e a afirmação do pessimismo na arte. Porém, para o filósofo, não é exatamente na tragédia grega que essa característica se confirma plenamente, mas sim no drama moderno. Ele chega a afirmar que a tragédia moderna seria superior à grega exatamente por isso. Se o herói antigo exibe uma submissão ao destino inevitável e à vontade inflexível e errática dos deuses, mas não abandona a vontade de viver. Mais tarde, Nietzsche usará exatamente esse argumento contra Schopenhauer, para dizer, enfim, que a tragédia não conduz à resignação, mas sim à superação do terrível. Para Cacciola, em 
"Schopenhauer e a questão do dogmatismo", 5 o conhecimento é a única possibilidade de libertação do jugo da vontade, a única fonte da vida estética e da vida ética, que significam, respectivamente, contemplação e resignação. Seria nesse sentido que o filósofo de Frankfurt afirmou que a resignação é a essência do trágico. Assim, do mesmo modo que a sexualidade constitui o verdadeiro e inapelavelmente preciso foco da vontade humana, enquanto esta se afirma, assim também a resignação e a supressão da vontade indicam a passagem para o ponto de vista ético em que a vontade sublimada, em uma grande reviravolta do destino, nega a si mesma. Mas por que isso deveria acontecer se, para Schopenhauer, o homem é impulso sexual concreto e o desejo constitui a sua própria essência? Para Nietzsche, de um ponto de vista psicológico, haveria nisso uma decisão arbitrária, que somente motivos íntimos ligados justamente à questão da sexualidade poderiam explicar. A visão dionisíaca do mundo, que afirma a vida, opõe-se à negação da vontade e especialmente o pensamento de Schopenhauer, mencionado acima, de que a tragédia conduziria à resignação: "Quão diversamente falava Dioniso comigo! Quão longe de mim se achava justamente todo esse resignacionismo!"'. Segundo Nietzsche, o resignacionismo não corresponderia à psicologia do trágico: "A tragédia precisamente é a prova de que os gregos não foram pessimistas: Schopenhauer enganou-se aqui, como se enganou em tudo"7. Para Nietzsche, ao contrário do que escreve Schopenhauer, a bela aparência teria a clara função de permitir a experiência do terrível e a sua assimilação universal, levando a vida adiante, isto é, afirmando o querer-viver e a destruição, estabelecidos como pressupostos da criação. O movimento de báscula do conceito de sublimação do terreno moral para o estético põe em relevo o debate com Schopenhauer e evidencia tanto a questão do perspectivismo das interpretações e da necessidade de autossuperação quanto também a da generalização do fenômeno estético como originária da relação de objeto. O que é próprio da natureza do impulso (ou seja, seus alvos e objetos variáveis) seria também, para Nietzsche, o que definiria a sutilização e sublimação como características originárias do próprio impulso e a metáfora como o seu representante no campo da linguagem.

No entanto, considerando o que já dissemos anteriormente, o próprio Schopenhauer ressalta que os gregos não são o exemplo mais bem-acabado de resignação, pois os antigos "não haviam atingido o cume e o objetivo da tragédia, ou mesmo a visão da vida em geral". Para Schopenhauer, os antigos "exibiam pouco da do espírito de resignação, pouco se afastavam da vontade de vida” (W II, 2, p. 111). Nesse sentido, a essência do argumento de Nietzsche é válida, no sentido de negar a resignação, mas ele se confunde quanto à compreensão que Schopenhauer tinha dos

${ }^{5}$ CACCIOLA, Schopenhauer e a questão do dogmatismo, p. 112.

${ }^{6}$ NIETZSCHE, KSA I, p. 19-20. Trad. de J. Guinsburg, p. 20.

${ }^{7}$ NIETZSCHE, KSA VI, p. 309. Trad. Paulo César de Souza, p. 61.

Voluntas: Revista Internacional de Filosofia - periodicos.ufsm.br/voluntas - Santa Maria - Vol. 9, n. 1, jul.-dez. 2018, p. 67-83. 
antigos, na verdade uma visão até mesmo um tanto próxima do que pensava o autor de $O$ nascimento da tragédia. Para Schopenhauer, haveria no máximo um sentimento obscuro entre os trágicos gregos de que poderia ser melhor não amar o mundo e a vida, e nunca uma viragem propriamente dita do querer. Curiosamente, para ele, os genuínos efeitos trágicos da catástrofe, a saber, a renúncia do herói e a exaltação espiritual produzida por ela, aparecem de forma distintamente expressa não em uma tragédia, mas sim em uma ópera, "Norma" de Bellini, especialmente no, aliás, belíssimo dueto Qual cor tradisti, qual cor perdesti. Na verdade, Schopenhauer considerava essa obra "um verdadeiro modelo da trágica disposição dos motivos, do trágico sequenciamento e desenvolvimento da ação, juntamente com o sublime e inefável efeito desses elementos sobre o estado de espírito dos heróis" (W II, 2, p. 113).

De qualquer modo, em Schopenhauer, a relação entre o caráter e o destino inexorável servem tanto para explicar a vida como a tragédia que expressa igualmente a mesma condição humana fadada ao conflito que no caso do espetáculo trágico é apresentado em sua magnitude suprema, como algo terrível e que suscitaria, para o filósofo, a conversão ao estado de renúncia, à negação do querer-viver.

\section{Existência prática e teatralidade}

O conhecimento profundo e mesmo a sabedoria adequada estão enraizados na apreensão intuitiva das coisas. Esta tem sido sempre o processo de geração, em que cada verdadeira obra de arte, cada ideia imortal, segundo o filósofo, recebeu a centelha da vida. Não é privilégio de Nietzsche dar valor à intuição como um exército móvel de metáforas, como vimos acima. Também em Schopenhauer, "todo pensamento original e primário acontece em sentido figurado” (W II, 2, p. 32). Porém, essa apreensão puramente intuitiva da existência é perturbada, como vimos na primeira e mais longa seção deste escrito, pelas relações de nosso intelecto com a vontade. Em geral percebemos como somos.

Aqui é inevitável a comparação do homem comum com o animal, por um lado, e com o gênio, por outro. Aquilo que não faz referência à própria vontade não existe para a pessoa comum que, nesse sentido, aproxima-se mais do animal do que do gênio. Por esta razão, ocasionalmente nos surpreende que mesmo as mais inteligentes pessoas e animais não notem alguma coisa que é evidente em si mesma; por exemplo, os animais não se espantam com alterações evidentes na nossa pessoa ou no ambiente. No caso de uma pessoa comum, as relações indiretas e, de fato, as relações possíveis com a vontade são adicionadas, e a soma delas constitui o conjunto dos conhecimentos úteis, o que já nos diferencia bastante do que podem os animais, mesmo os mais inteligentes. Mas, mesmo nessa situação o conhecimento permanece confinado às relações. De acordo com isso, uma imagem totalmente pura e objetiva 
das coisas não é alcançada pelo intelecto comum, porque a sua Anschanungskraft logo se cansa e essa força e capacidade de intuir se torna inativa, a não ser que seja novamente estimulada e posta em movimento pelo querer-viver. Pois, por si mesma, não tem energia suficiente para apreender o mundo puramente objetivo a partir de sua própria elasticidade e sem uma finalidade [zwecklos]. Aqui precisamos talvez do auxílio do conceito metapsicológico de libido, de Freud, que explica justamente essa ativação íntima através de uma energia sexualizada. Tanto o psicanalista quanto o filósofo colocam todo interesse sob a égide da sexualidade. Raramente há um excedente de libido na ativação do intelecto que permita a ele alcançar resultados efetivamente superiores que lhe permitam se banhar longamente nas puras fontes da intuição intelectual do mundo, e também das pessoas e das coisas que nele existem. Segundo Schopenhauer, há um ar de família entre as pessoas geniais, que os distingue geração após geração, devido a essa libertação do intelecto da servidão da vontade.

\begin{abstract}
Quando o poder do cérebro de formar representações expõe tal excedente que uma pura, distinta e objetiva imagem do mundo externo aparece sem uma finalidade e como algo inútil para as intenções da vontade, a qual é ainda mais perturbadora nos graus mais elevados e pode mesmo se tornar prejudicial para ela — então já existe pelo menos a disposição natural para essa anormalidade que é indicada pelo nome de gênio, o que assinala que algo estranho à vontade, ou seja, ao próprio Eu, um gênio acrescentado de fora por assim dizer, parece se tornar ativo aqui. Para falar sem metáfora, no entanto, o gênio consiste em que a faculdade de conhecimento tenha recebido um desenvolvimento consideravelmente mais poderoso do que o exigido pelo serviço da vontade [Dienst des Willens], para o qual sozinha aquela originariamente veio a ser. Portanto, estritamente falando, a fisiologia poderia de certa forma classificar este excesso de atividade e massa encefálicas entre os "monstra per excessum", que, como sabemos, ela associa aos "monstra per defectum" e aos "monstraper situm mutatum" (W II, 2, p. 32).
\end{abstract}

Os termos usados acima pelo filósofo denominam monstruosidades "por excesso", "por defeito" e "por uma posição errada". O gênio consiste, portanto, em um intelecto poderoso dotado de uma vontade igualmente forte, o que, em termos freudianos seria justamente essa capacidade da libido de se voltar violentamente, fisiologicamente, para a própria atividade intelectual, com forte capacidade sublimatória, o que certamente estaria barrado à pessoa comum. No entanto, o homem prático, que também se parece com todos os outros homens práticos, justamente por ter seu intelecto mais claramente servindo ao querer-viver e aos desígnios da vontade inconsciente, com seus alvos comuns e geralmente mesquinhos, apresenta uma capacidade maior para perceber o que deve fazer nas situações práticas. Se o homem de gênio nos revela a natureza da existência, o homem comum sabe melhor como fazer para viver no chão negro dessa existência cheia de acontecimentos que exigem nossa atenção cotidiana. Se o gênio pode captar do mundo seus elementos 
efetivos e a partir deles conceber uma obra trágica que expresse perfeitamente a natureza da existência, ao viver suas ações talvez nos façam pensar mais nas personagens cômicas, canhestras, que por sua inabilidade, fazem por vezes um papel ridículo. A vida, como todos sabem, costuma ser irônica e nos impõe perdas sempre de acordo com nosso caráter, capacidade e posição. Assim também o homem comum, inversamente, exatamente por ter seu intelecto melhor adaptado à vontade e suas relações, adapta-se melhor à tragicomédia da existência, embora a sua capacidade de concepção intuitiva das coisas seja efetivamente limitada se comparada à do gênio. Mas tem, muitas vezes, a sagacidade presente na natureza inteira em relação aos seus objetos de interesse. Portanto, se a ele não se destinam as relações mais elevadas, pode mesmo assim se guiar no mundo com um grau mais ou menos elevado de sabedoria prática, com a intenção de superar os obstáculos impostos pela experiência.

De acordo com o exposto acima, cada um de nós terá que fazer escolhas mais ou menos sensatas, mais ou menos de acordo com as situações efetivas, o que certamente vai depender de bom senso que, apesar de todos julgarem ter de sobra, é, de fato, muito mal distribuído entre as pessoas. Se a vida em seus momentos graves e extremos se assemelha à tragédia, é preciso admitir que habitualmente ela se assemelhasse mais talvez a uma comédia, já que as personagens comuns com as quais convivemos habitualmente, com seus sofrimentos mesquinhos, suas tolices e as reviravoltas trôpegas de seus destinos, trazem consigo no mais das vezes, tanto pelo seu caráter quanto pelas suas ações, o material inesgotável para as risadas. Mas, as risadas que a Humanidade provoca em si mesma, na vida prática, trazem sempre consigo o secreto temor de que nós mesmos pareceremos ridículos, ou até mesmo infames, em certas situações. Essa é uma grande fonte de sofrimentos e inibições cotidianas no conjunto da humanidade. É nesse sentido que o drama da existência reaparece diante de nós, dessa vez como trama farsesca e em grande medida, novamente, como algo que talvez não devesse existir, ou, pelo menos, como uma pantomima na qual preferencialmente não deveríamos ser nós os objetos das risadas. Por isso o cuidado com a imagem que a maioria das pessoas manifesta e que é inclusive recomendado pelo filósofo em sua obra tardia.

Em Schopenhauer vemos que a necessidade cotidiana nos leva a considerar a sabedoria de vida como uma atuação em certa medida teatral, já que em sociedade não se pode ser completamente autêntico (Freud vai dizer a mesma coisa, exatamente quando o psicanalista, em seus escritos técnicos, compara a vida social com a clínica, onde idealmente se deve dizer toda a verdade sem pestanejar e é nisso que consiste a livre associação). Há, portanto, uma técnica da vida prática que exige certa dose de inautenticidade, uma contenção das palavras e das ações, e, com isso, certa teatralidade que evita o infortúnio, já que as pessoas suportam apenas uma pequena medida de verdade e as coisas sempre podem virar contra nós quando não sabemos como agir. A vida prática depende da correta percepção dos motivos que, por assim dizer, corrige 
o desencontro entre a satisfação da vontade e a necessidade. Por isso o filósofo vai dizer que "na vida prática, o gênio é tão inútil quanto um telescópio em um teatro". (W II, 2, p. 45.) Nesse mesmo sentido, à maneira de Gracián, Schopenhauer entende que o gênio precisa se esconder na vida prática, pois a presença de pessoas que nos são superiores desperta em nós desconforto, quando não ressentimento e ódio junto com a admiração. Dificilmente alguém que é reconhecido como superior não nos ofuscará diante dos outros. Nesse sentido, Gracián recomenda que, em termos práticos, caso queiramos nos destacar, procuremos a companhia de pessoas menos talentosas. Por outro lado, o ônus das pessoas superiores é serem admiradas, porém não amadas, o que deve sempre despertar a suspeita quanto aos possíveis golpes do destino, leia-se ressentimento, posto que os ressentidos são muitos e eles podem se unir contra as pessoas que se destacam por suas elevadas capacidades e concepções. Portanto, há aqui uma equação difícil de ser resolvida na existência prática, que Schopenhauer, tradutor de Gracián, vai colocar nos seguintes termos: O que alguém representa "para si" e o que alguém representa "para os outros". A honra está situada no que representamos para os outros, mas o nosso valor interno, por outro lado, nos define para nós mesmos, trata-se, portanto da difícil arte de termos consciência de nosso próprio valor. Schopenhauer, em seu tempo, foi extremamente sensível a esse problema, pois teve que esperar longo tempo pelo reconhecimento de sua obra, o que só ocorreu em idade bastante tardia. Nesse sentido, de acordo com o espírito de sua obra, recomendava que não se esperasse muito da vida e, isso sim, dedicássemo-nos às nossas qualidades interiores, pelo que o cultivo de nosso mundo íntimo, a leitura de livros, a apreciação das belas artes e da música, selecionando para nós mesmos o que a humanidade melhor produziu em todos os tempos. Escreve o filósofo:

O que, em última instância, importa para o nosso bem-estar é aquilo que preenche e ocupa a consciência. No geral, toda ocupação intelectual proporcionará, ao espírito capaz de executá-la, muito mais do que a vida real com suas alternâncias constantes entre sucesso e fracasso, acompanhados de abalos e tormentos (A, p. 159).

Porém, como já foi dito aqui, essa dedicação ao nosso mundo interno, por outro lado, faz com que as pessoas se tornem menos aptas para as exigências da vida prática. Esse pêndulo entre recolhimento e vida mundana, de qualquer modo, depende de o quanto necessitamos de cada uma dessas coisas e para saber até onde ir com cada uma delas dependemos de clareza de consciência que advém da experiência.

De um modo geral, para viver com perfeita clareza de consciência e extrair da experiência toda instrução nela contida, é necessário refletir sobre o passado e sobre nossas vivências, para colocar nossos planos em perspectiva, o que para ele, é "a repetição das aulas particulares que a experiência deu a cada um” (ibidem, p. 160). 
Apenas reflexão e conhecimento sem nenhuma experiência, ou o contrário, não acabam bem, perde-se a clareza de consciência.

Nesse mesmo sentido, sempre será mais feliz, de acordo com ele, aquele que basta a si mesmo, e só se pode ser como se é, quando se está perfeitamente sozinho. (A, p. 161). E quão mais valor tiver a personalidade de uma pessoa, melhor apreciará a própria solidão. Por outro lado, também será mais solitária de outra forma, ou seja, exatamente quando precisar conviver socialmente, pois, se a natureza provê seus dons de maneira desigual, a sociedade humana "iguala todos os seres" (ibidem, p. 162), ou pior, "coloca no lugar da diversidade as diferenças e degraus artificiais de classe e posição, com frequência diametralmente opostos à escala hierárquica da natureza". (Idem) Assim, a sociedade obriga o indivíduo superior a uma paciência sem limites com qualquer "insensatez, loucura, absurdo, obtusidade" (ibidem, p. 163).

Disso decorre aquilo que tomamos como ponto de partida em nossas considerações sobre a necessidade de sermos, em certa medida, personagens de nós mesmos no palco da vida, pois os méritos pessoais devem frequentemente se ocultar. Assim, já que a pessoa superior "fere pela sua mera existência" (idem), dela é exigido que se desfigure, que se oculte, que se encolha, para não despertar francamente o ódio das outras pessoas. Nessa sociedade, por conseguinte, temos de renunciar, com doloroso repúdio (Verleugnung) a nós mesmos, a três quartos do que somos, “a fim de parecermos com os demais". (Idem) Ter as outras pessoas nessas condições é outra daquelas vantagens que não cobrem a perda, pelo que o negócio resultaria em prejuízo. Nesse sentido, a troca do convívio social pela solidão é vantajosa. A vida em sociedade, pelo contrário, é insidiosa, pois “oculta males enormes" (ibidem, p. 164) por trás das aparências e exige o mesmo de nós se quisermos conviver com os outros.

Schopenhauer compara a sociedade a um fogo no qual "o indivíduo inteligente se aquece a uma distância apropriada, e não como o insensato que mete as mãos dentro dele" (Ibidem, p. 179). Uma das formas de fazer isso é justamente ocultar parte de nossa personalidade com a finalidade de nos adequarmos à companhia que temos: Colocamo-nos no mesmo nível de nosso interlocutor, pois tudo o que temos em excesso desaparece e até mesmo o repúdio de nós mesmos que isso exige é ocultado do outro, o que permite, enfim, com que nos relacionemos com ele, tornando-nos "comuns" (ibidem, p. 205). Por outro lado, há certas circunstâncias e certas pessoas que é melhor evitar, justamente porque não é possível, na companhia delas, utilizar os disfarces exigidos para estar de acordo com tais personalidades. Diante de pessoas imbecis, de loucos, excessivamente vulgares, ignominiosas, o melhor é não falar com elas. 


\section{Conclusão}

Os três aspectos da teatralidade que procuramos expor e analisar aqui são complementares e correspondem, de um modo geral, aos diferentes aspectos que se apresentam diante do filósofo através das metáforas da casa de espetáculos, seja ela o mundo ou nossa cabeça, e a das marionetes, que representa a cena do mundo controlada intimamente por nossa vontade, que é essencialmente inconsciente:

O intelecto do homem normal, estritamente vinculado ao serviço de sua vontade e, portanto, na realidade, ocupado apenas com a recepção dos motivos, pode ser comparado ao complexo sistema de fios pelo qual as marionetes que são exibidas no palco do teatro do mundo são postas em movimento. A partir disto, surge a seriedade seca e grave da maioria das pessoas, que só é superada por aquela dos animais, que nunca riem. Por outro lado, o gênio, com o seu intelecto sem restrições, pode ser comparado a uma pessoa viva atuando entre os grandes fantoches do famoso espetáculo de marionetes de Milão (W II, 2, p. 46.).

No homem comum, esse produto de fábrica da natureza, o intelecto apenas serve estritamente à vontade, aos alvos do interesse comezinho e egoísta atrelados ao querer-viver. Por isso aquele é comparado às marionetes do espetáculo milanês. Essa metáfora é recorrente em Schopenhauer, como já deixei entrever através das citações feitas até agora nesse artigo e vale comentar aqui, em função disso, que ela exprime especialmente o poder do inconsciente sobre a consciência, para falar em termos psicanalíticos. Assim, somos, no mais das vezes, "agidos" (como escreveu Nietzsche em Além do bem e do mal) através de racionalizações, satisfações substitutivas e outros artifícios semelhantes, outras máscaras. Já a atividade do gênio corresponde ao caráter não sintomático da reflexão genuína e da arte, que expressam a verdadeira arte de viver, isto é, a elevada arte da sublimação.

Mas, justamente o homem genial é (conforme o poeta Charles Baudelaire) um albatroz, príncipe das alturas, que quando desce à terra arrasta as suas grandes asas desajeitadamente no chão, ou seja, aquele que enxerga o conjunto e a natureza da experiência tem dificuldade, por outro lado, de lidar com questões simples e banais da experiência.

Desse modo, conclui-se que o homem comum saberá se conduzir com maior eficácia quanto ao que tratamos nessa terceira parte do texto, isto é, a arte de evitar tanto sermos os protagonistas de uma tragédia quanto os de uma comédia, o que, em grande medida, como dissemos, trata-se de uma arte de simulação.

Essa questão da simulação necessária tratada na última sessão de nosso texto, guarda relação com a nossa capacidade de estarmos sozinhos, pois as coisas, segundo o filósofo, são belas de ver, e difíceis de viver. Se conseguíssemos ser de fato solitários, existiríamos cada um como um novo Adão sobre a Terra, mas como cada um de nós 
nasceu de pai e mãe, temos também a necessidade de convívio, de extrair um mínimo que seja de satisfação do contato social, ainda que isso também nos custe sempre "os olhos da cara", já que o convívio em sociedade, normalmente, é um negócio que não cobre os seus custos.

\section{Referências bibliográficas}

CACCIOLA, M. L. Schopenhauer e a questão do dogmatismo. São Paulo: EDUSP, 1994.

FONSECA, E. R. Psiquismo e vida: Sobre a noção de Trieb nas obras de Freud, Schopenhauer e Nietzsche. Curitiba: Editora UFPR, 2012.

FREUD, S. Das Werk. Edição Eletrônica das Obras Completas. Berlin: Heptagon Verlag, 2010.

NIETZSCHE, F. KS A Kritische Studienausgabe. Org. Giorgio Colli e Mazzino Montinari, 15 vols., Munique, DTV/ de Gruyter, $2^{a}$ ed., 1999.

NIETZSCHE, F. Genealogia da Moral: Uma Polêmica. Trad. e notas de Paulo César de Souza. São Paulo: Companhia das Letras, 1998.

NIETZSCHE, F. Ecce Homo - Como alguém se torna o que é. Trad. e notas de Paulo César de Souza. São Paulo: Companhia das Letras, 2005.

SCHOPENHAUER, A. Sämtliche Werke, ed.Wolfgang Frhr. von Löhneysen, Frankfurt, 1986, 5 vols.

SCHOPENHAUER, A. Über den Willen in der Natur, vol. 3, 1836.

SCHOPENHAUER, A. Die Welt als Wille und Vorstellung, Ergänzungen, [O Mundo Como Vontade e Representação: Complementos] - 1844 (2 a. ed.); 1859 (3a. ed) (O mundo como vontade e representação: Complementos. Volumes 1 e 2.). Trad. e notas de Eduardo Ribeiro da Fonseca. Curitiba: Editora UFPR, 2014.

SCHOPENHAUER, A. Aforismos para a sabedoria de vida. In: Parerga und Paralipomena, I/II, SWV,VI - 1851. Tradução de Jair Barboza. São Paulo: Martins Fontes, 2002. 
83 | Schopenhaner e o teatro: ilusão, resignação e sabedoria de vida

Recebido: 18/11/18

Received: 11/18/18

Aprovado: 26/11/18

Approved: 26/11/18 